\title{
"From my memory you will not be vanished." Assessing the digital image in the preservation of Lav Diaz's MiniDV work
}

Luke Moses

Since 2016, an effort has begun to preserve the works of filmmaker Lav Diaz's early digital production (circa 2004-2009) (Moses, 2017). The project has been supported by New York University and the Austrian Film Museum (Moses, 2017). This period marked Diaz's shift into digital filmmaking with the use of the Panasonic AG-DVX100 MiniDV camera. The AG-DVX100, released commercially in 2002, was embraced internationally by filmmakers as diverse as Pedro Costa and the Duplass brothers as a cheap and mobile alternative to film and earlier digital cameras (Burdeau, 2007; Debruge, 2013). After a frustrating period of shooting $35 \mathrm{~mm}$ films within the Filipino studio system, the impact of the MiniDV technology on Diaz was immense, sparking a period of formal and philosophical innovation in his practice (Baumgartel, 2012). The works shot on the AG-DVX100 - Evolution of a Filipino Family (2003), Heremias Book One (2006), Death in the Land of Encantos (2007), Melancholia (2008), and Butterflies Have No Memories (2009) - would define his now-recognizable style and become hallmarks of a new golden age of Philippine cinema. A technical history of these works has led to an approach that separates preservation and restoration, while utilizing both in order to respect the works and the artist's original intent.

After Diaz began to shoot Evolution of a Filipino Family on $16 \mathrm{~mm}$ in 1994, production expenses proved prohibitive (Tioseco, 2006). To continue, he adopted the affordable AG-DVX100 camera despite initial misgivings about the implications of the digital image. Use of the camera 
would immediately spark an evolution in his artistic practice. Utilizing the MiniDV's capacity for recording up to an hour, Diaz began to explore a distinctly Malay concept of cinema unconcerned with the passing of time, in opposition to the regimentation and manipulation of the Western/ Hollywood mode of filmmaking (Baumgartel, 2012). The stark black-andwhite image, an aesthetic signature, was initially a response to the perceived ugliness of the digital image in color. Use of black and white helped to mitigate the otherwise jarring juxtaposition of film and digital image, but also lent a poetic quality to the director's allegorical work. The aesthetics of the digital image was intrinsically linked to the creation of these works; however, a layer of digital error, of audiovisual artifact resulting from tape transfer or duplication, would also become part of the common experience of seeing these works.

For Diaz, and many artists operating within the paradigm of independent cinema, post-production was directly influenced by the requirements of exhibiting within the international film festival circuit (Moses, 2017). With most local movie theaters only screening mainstream fare, and the general lack of alternative/arthouse venues, Diaz found support from festival programmers in Toronto, Rotterdam, and Locarno, among others. In the early years of the millennium, before the wide adoption of digital projection and the Digital Cinema Package (DCP), the works were commonly exhibited on videotapes through a MiniDV player or camera (Moses, 2017). The lengthy duration of Diaz's works meant that each had to be exported back to sets of tapes (as many as twelve) and swapped by hand throughout each screening. Most copies were also hardcoded with English subtitles, a standard for international film festivals at the time.

A pattern would develop in Diaz's practice: after screening at a few (mostly European) film festivals, each work was relegated to the occasional screening requested directly from Diaz himself or one of the few institutions, such as the Austrian Film Museum, that made a concentrated effort to collect his works. Digital artifacts introduced at unknown points in the process of capturing or duplicating tapes would remain in most circulated copies, but with a lack of audience outside of the film festival circuit, and digital distribution still nascent, there was little incentive to spend time or money to create new copies (L. Diaz, personal communication, May 27, 2017). Focus instead went toward producing entirely new works, a process that required fundraising efforts from cultural grants or artistically minded producers. The arrival of a new source of funding might mean an immediate shift in focus and priorities (L. Diaz, personal communication, May 27, 2017). 
It is within this framework that exhibition copies would become de facto master copies. By Diaz's own estimation, the sets of videotapes in the Austrian Film Museum's collection are the best copies of the works currently in existence, though they do display some evidence of duplication (Moses, 2017). Preliminary research appears to confirm this, with other copies in circulation displaying more noticeable audiovisual artifacts. Furthermore, no known copies exist without hardcoded subtitles in English (such as the tapes in the Museum's collection) or Italian (the result of pirated copies from a television station). While the recent discovery of camera original footage has created a chance to revisit the works in restoration (Moses, 2017), it has been determined that a two-pronged approach would best suit a faithful preservation of the works. The first, a direct capture of the Austrian Film Museum tapes to uncompressed digital video files will preserve a facsimile of the most commonly seen version of these works. Second, and separately, new captures of the camera original tapes will remove artifacts introduced through transfer and duplication and allow for the possibility of soft/optional subtitles in a way that translations won't compete for space around hardcoded subtitles. The use of both approaches can bring the work closer to the artist's original intention while maintaining a version as it most commonly existed in its historical context.

\section{References:}

Baumgartel, T. (2012). Digital is liberation theology: Interview with Lav Diaz. In T. Baumgartel (Ed.), Southeast Asian independent cinema (pp. 171-178). Hong Kong: Hong Kong University Press.

Burdeau, E. (2007). Pedro Costa, d'arrière en avant. Retrieved from https://fidmarseille.org/joomla/2007rospective-pedro-costa/.

Debruge, P. (2013, August 22). Indie directors Jay and Mark Duplass find peace in new age of filming. Retrieved from https://variety.com/2013/film/news/jay-and-mark-duplass-surprise-with-sunnyoutlook-1200585271/.

Moses, L. (2017). Tape death in the land of encantos: Preserving the video works of Lav Diaz (unpublished master's thesis). New York University, New York City, NY.

Tioseco, A. (2006, January 30). Indictment and empowerment of the individual: The modern cinema of Lav Diaz. Retrieved from http://www.criticine.com/interview_article.php?id=21.

LUKE MOSES is a Time-Based Media Art Conservation Specialist at the Smithsonian American Art Museum. He previously worked at Kino Lorber, the Frick Collection, and New York University, where he also received in 2017 an M.A. in Moving Image Archiving and Preservation. Since 2016, he has been working to preserve the video works of Lav Diaz. (Corresponding author:IIm318@nyu.edu) 
